\title{
12. Talking About Sex: On the relationship between discourse, secrecy and sexual subjectivity in Melanesia
}

\author{
Gilbert Herdt
}

\begin{abstract}
All human societies are concerned with the regulation of sexuality - a truism of anthropology. And all of them, past and present, exert cultural, political, economic and even psychological controls over how people talk about sex: when, where, with whom and why - not why they are motivated, but why they must be stopped from sexual discourse. These barriers to sexual communication are created for a variety of reasons - notably, gender power, the strictures on childhood sexual and gender development, the regulation of the development of pleasure, the social control of adult morality and the inhibition of sexual behaviour that violates norms in such fundamental areas as premarital and extramarital sex and same-sex relationships. The form that sexual objectification takes in a particular society reflects, refracts and reproduces these conditions of discursive control.
\end{abstract}

Of especial interest to this comparative essay on the Sambia of Papua New Guinea is the fundamental issue: who is sexually objectified in the course of development and why? Among the Sambia, it was the male body that was objectified, and ritual secrecy was critical to its success. These are the issues that inform this chapter, which I offer in honour of the late Don Tuzin, friend and colleague for more than three decades and someone from whom I learned much about these issues in regard to masculinity, male cults and the utopian aspiration of men to seek what he called a 'safe haven' in their dealings with the world. Don was long interested in the scope and meaning of sexuality in Melanesia, and his great ethnography The Voice of the Tambaran (1980), as I have suggested elsewhere (Herdt 2003), was both an inspiration and a source of puzzlement in elucidating these issues. In Don's subsequent work The Cassowary's Revenge (1997), I believe that he found a partial solution to the question of the social regulation of sexuality and discourse, and I will return to this point at the end of this chapter.

Pre-colonial Melanesian societies influenced sexual talk in myriad ways that suggest desires are socially constructed at most times, for most people, in all of these societies. Ironically, I was reminded of this still-radical claim when reading Michael Young's (2004) brilliant biography Malinowski: Odyssey of An 
Anthropologist, wherein we find a young Omarakana-resident Malinowski, horny, a hypochondriac and a linguistic genius, describing how Trobriand Islanders inserted sexual discourse into their everyday lives such that he could blush (see, for example, Young 2004:404-5). Ironic because, of course, the Trobriand Islanders were matrilineal in ideology and companionate in their attitudes towards women, creating high-status female roles unknown to Highlands Papua New Guinea. Trobriand sexual desires were commonly folded into social relations, and their expression, while carefully metered by custom, ritual and taboo, was more permissive and fluid than in middle-class American mores even today, especially as pertains to childhood sexual development (Herdt 2009a). I think Margaret Mead (1928) made a similar point about Samoa.

The Sambia people of Papua New Guinea, with whom I have lived and worked since 1974, were traditionally much more restricted in their sexuality. ${ }^{1}$ Their culture, however, structured these tendencies into sexuality, social organisation and speech through the mechanism of ritual secrecy - a high form of utopian male culture that produced sexual hierarchy and exaggerated gender differences. War and what I shall variously refer to as conditional masculinity as well as the sexual politics of marriage were root causes. Day in and day out, Sambia were compelled to talk about their sexual roles and fears; but by doing so, they created a language of desire and transgression hidden from the public. They did this through the institution of boy-inseminating rituals - their way of avoiding the intimacy of male and female interaction - but especially through the exquisite secrecy that could screen, hide and manipulate even raw sexuality in the presence of children and women. The emotionality of these actions suggests that they were not simply political tactics but rather deeply motivated subjectivities.

These dynamics among the Sambia created a lifelong hidden discourse of repression and sexual objectification, and I shall try to reveal them through conversation with the two greatest theorists of sexuality in the twentieth century: Freud and Foucault. Contra Freud (1904), who believed that sexual repression was a universal developmental pattern, and contra Foucault (1980), who argued that sexual discourse was inherently a historical reality of state control over individuals in the transition to a modern sense of selfhood, I will argue that among the Sambia the implementation of ritual secrecy actually created the sexual objectification of the male body. Among the Sambia and their Anga neighbours, the social practice of ritual homosexuality or boy-insemination was the means to this form of male objectification, whereas elsewhere in Melanesia

\footnotetext{
1 The focus of this chapter is ethnographic research up to 1993; subsequent fieldwork reports on the conditions of radical change.
} 
ritual secrecy resulted in myriad forms of homo-sociality that were not explicitly homoerotic (Herdt 1993). In both cases, however, ritual secrecy ensured a form of male agency that would not otherwise have prevailed.

Why did the Sambia-and, by implication, a variety of other Melanesian peoples like and unlike them in the practice and meaning systems of their sexual cultures - take such great pains to regulate, manipulate and otherwise inhibit talk about sex? So desperate were they to control sexual speech, they actually created a world of secrecy and hidden desires that sometimes foiled their own designs.

Like many Melanesian sexual cultures, the Sambia institutionalised a rare and fragile mechanism of social regulation of thought, speech and action unknown to modern society: secrecy - that is, ritual secrecy to be precise-implemented through the embodiment of ritual initiation, the modus operandi for psychocultural regulation in their society. How can we understand the impact of this set of complex, situated, discursive and power relationships on the development of sexual subjectivity for individuals? These are questions explored in my 2003 book, Secrecy and Cultural Reality, but here I shall attempt to go a bit further in contrasting why neither Freud nor Foucault is adequate in explaining the phenomena.

While not exactly Foucaultian inspired, my interrogation of sexual control, power and the harnessing of sexual speech on behalf of the reproduction of total systems does engage the way in which the French thinker Michel Foucault (1980) worried over the means and ends of power, state manipulation of bodies and minds, and the creation of what has come to be known as 'bioforce', which might transcend these constraints. Foucault's perspective on these issues suggested that discursive state control of sexuality in the modern period became the primary means of how societies imposed new norms of intimate relationships, identities and citizenship more broadly.

In fact, Foucault's Discipline and Punish (1995), as is well known, took as its brief the notion that the advance of modernity in the regulation of individuals was made possible in part by the creation of the 'norm' as a fundamental category in human development and social life. Ritual secrecy is to the norm what Westerners today experience as self-censorship.

Beginning in the 1960s, and terminating with his death in 1981, and most importantly, with the publication of The History of Sexuality, Foucault built a compelling and powerful counter-hegemonic discourse following upon nearly a century of sexology and the domination of Freud over the central question: why do we talk about sex? Note, however, what a curious thing it is that Foucault's book really is not about history at all; it tells very little about sexual 
subjectivity, it virtually ignores gender, it defuses the study of power relations, and it invents and then rejects what Foucault calls the 'repressive hypothesis' of Freud. To paraphrase him, not only was 'sexual repression' assumed by Freud to be a universal psychic reality, but the more the individual, innate dispositions were studied, the less were power and society even considered relevant to understanding the nature of sexual repression. The doctor could diagnose what was wrong with the patient but ignore the social reality of the person's realworld frustrations and social life. Freud's model suggests an individual process impervious to social change, making the changing meanings of sexuality impossible or at least irrelevant. Never mind that The History of Sexuality - so much based upon bourgeois nineteenth-century France-is no better informed by anthropology than was Freud's Totem and Taboo, from 1913.

Nevertheless, just as everyone of my generation had to confront the genius of Freud and many of us were psychoanalysed, for better or worse, Freud's toomentalist, patriarchal legacy strongly influenced anthropological and sociological studies of sexuality for decades. Indeed, in the field of sexuality today, it is hard to imagine the counter-discourse without Foucaultian theory, with its concerns about sexuality and the reproduction of social inequalities - both at home and in the colonies - of a society. Foucault's critique of the 'repressive hypothesis' that is, Freud's assertion that sexual wishes and conflict, often over oedipal strivings, understood by the triangulated drama of father/son/mother-lay at the heart of the developmental story of the child about age five, and his final subjectivity.

It was stupendously wrong as a theory, Foucault claimed; for what Freud had taken to be a psychical reality - sexual drives to compete with the father in order to possess the mother and destroy the rival - was not contingent upon person, time, culture or conduct. But how could that be so, Foucault asked? History had determined this repression and its contents - in fact, very recent history: the kind that was closely tied to the schizophrenia of Victorian gender and sexual politics in Freud's patients, as well as moral panics about masturbation, social movements that promoted the creation of the new identity of homosexuality about 1870, and a concomitant range of social things we anthropologists would call 'local culture' (Herdt 2009a).

And I would like to add that 'sexuality' — while being an umbrella term that conveniently covers such divergent areas of subjectivity as love, desire, sexual orientation, relationships and communities - seldom is defined in everyday discourse; and rarely does it communicate precision of meaning in general. It is far more effectively described and interpreted locally, in terms of the moral conventional system of particular beliefs, rules and meanings, also known as 
culture. This is especially true of sexual pleasure. Or, to paraphrase the immortal Tip O'Neil, all sexuality is local, none more localised than the actual meanings and expressions of pleasure.

Of course, much like Freud, Foucault did not have a burning interest in local culture, regarding 'civilization' as a means to an end (individual repression or freedom). Where he fell short was in his emphasis - some might say his obsession - on a rarefied sense of sexuality as discourse (Herdt 1999). The sense of agency, of individual subjectivity, is largely missing from Foucault's work; but that of course is not what the French scholar was primarily concerned about (Halperin 1995). Here, Freud is more firmly grounded, as he understood that the sexual was but one manifestation of a deeper set of embodied meanings, which discourse could disguise, transpose and hide. Was it not Freud who famously concluded Totem and Taboo with these lines: 'For the neurotic, as for the primitive, inthe beginning was the deed, not the word' (1955:164)-actions, not talk.

Thus, sexuality for peoples such as the Sambia, in Freud's grand theory, revealed a counter-tendency to act out passion, rather than to repress it, prior to the historical paradigm of Judaeo-Christian codes that narrated how, in the beginning, through God, was the Word, the Old Testament, breathing life into human existence, differentiating animal from the human; and how, with this creation, came the invention of sin, morality and the Oedipus complex. Culture from nature, Lévi-Strauss has said. In other words: a sexuality suited to civilization is one rooted in words.

I am reminded of a colleague from Thailand who once impatiently argued against American and Australian researchers - in a conference on HIV now 15 years ago: 'You Westerners only talk about sex-we do it! But we never talk about it - it's too embarrassing; and what's the point?' It is the gap between these two civilizations - between the talking versus the action of sex-that creates differential power relations, pleasures and risk. I will argue that this is part of the problem: in this void, we far too easily imagine that society is stable and cultural reality a given.

Nothing could be further from the truth for the Sambia. The harsh political facts of war and its destabilising effects upon their social organisation impinged upon them and made the mediation of ritual secrecy a tool in stabilising relationships, including the dangers of sexuality; secrecy was essential to the active and wilful creation of cultural reality. And with it came an intentional creation of sexuality - one that was not natural or normal at all in the modern sense of these terms. The Sambia thus were driven to repress some desires while producing and expressing others. Yet unlike Freud's prediction, Sambia sexual development continued the repression and the expression of what we would 
consider forbidden desires long past the age of five, and not within the oedipal triangle as Freud imagined it. Moreover, the Sambia did this through a system of power relations that made ritual its own engine for the production of desire and pleasure. Men were as much its victims as its victors on the level of discourse, though they had the upper hand with women and children, and the degradation of women, including the terrible manifestations of this in terms of wife-beating and other real-world violence, was cold and cruelly present in everyday life (Herdt 2006; Stolpe 2003).

The Sambia required married men and women to live together in small, round huts, internally divided into male and female spaces, as was common in New Guinea. Men, however, slept for long stretches in the men's house away from their families during wartime and ritual initiations (Herdt 1989). Strategically centred in the village were men's houses where initiated boys and older bachelors lived, while on the periphery and just below the village were menstrual huts. Secrecy surrounded two of the three abodes; only the married couple's house was a public space. And there, as Foucault might have predicted, the regulation of sexual talk was intense.

Traditionally, there were three different types of Sambia discourse: public talk (iyun-gacheru yungalu, lit. 'free talk'), secret talk (ioolu yungalu, lit. 'hidden talk'), and private talk (no marked category). Public discourse defined daily village gab and was associated with domestic situations in women's houses and casual gatherings on the plaza of a hamlet. Local meetings shaped how Sambia now used the Pidgin concepts tok publik (public talk) and tok hait (secret talk), because all ritual is tok hait. It caused them to refrain from talking about men's-house activities and especially homoerotic relations between younger and older boys, as well as the most secret of rituals, such as the nose-bleeding instrumentalities. In contrast, a married couple's own erotic relations were taboo but private, not secret, always to be hidden from children. Heterosexual coitus was a thing of the deep night, whenever everyone else was asleep; better yet, it belonged to the garden periphery, away from prying eyes. But all the adults knew of it and imagined its effects, always.

In the men's house, secrecy was instilled and reached its apex through six agegraded initiations that created among males the ritual status distinction between younger and older, between the ritual elders at the top and the young adepts, aged seven or eight, at the bottom. The degrees of knowledge, regulation of transmission of secrets to the next grade, hiding of sexual relations with women from younger boys, and shame that younger boys felt and were made to feel in the presence of their fathers, elders and male kin were emotionally intense - a broader oedipal circle. Beginning at an early age, then, boys were not to know of their parents' sexual lives, had hidden from them until initiation the homoerotic relations between older and younger initiates, and graduated into the status 
of hegemonic adult only after successive initiations during a 15-year period that brought them to marriage and fatherhood. Sexual feelings among boys and girls were strongly inhibited through a traditional culture as prudish as it was preoccupied with war. Thereafter, the nature of oedipal strivings went in different directions for the genders, as they do for us; but here, to engage Don Tuzin's theoretical interests, I shall discuss only the development of male sexual subjectivity through ritual.

A boy's development begins with subordination and repression but then transitions to a cultural reality that allows the creation of desires and their expression secretly. A youth must give up the receptor role and become the dominant player who bestows the gift of semen to younger initiates. But does the youth have enough semen and is his phallus sufficiently close to the image of being a warrior that he will not be silently mocked by the younger initiate who will drink his semen?

This question hangs in the transitional space from being the subject who desires penetration by the older male to becoming the bachelor who desires to inseminate a younger boy. The older youth also begins to anticipate sexual and marriage arrangements. A key informant, the youth Moondi, for instance, once told me how he began to fantasise about inseminating a favoured younger initiate soon after his third-stage bachelor ceremony. Until that time he had perceived himself primarily as an object, not as much as a subject, in the mythopoeic and secret practice of being male. He began to have wet dreams - first of inseminating boys and then of girls. Within the year, though, he began for the first time to consciously desire women, specifically a younger woman betrothed to him, whom he eventually married.

Thus is duty transformed into pleasure. Secret obligation assumes the intimacy of a community of believers who yearn for support from each other and a mode of self-rationalisation in all of the meanings of their public actions. Where the boys begin actively resisting separation from their mothers' bodies and yearn to return to their fold, years of living in the men's house and learning ritual teachings of women's pollution actively transform the boys' desires for renunciation into active fear of menstrual blood, with its traces on the female body. Merely to think of menstrual blood, or the public metaphor for it, is to produce compulsive spitting by a man, since he has taken the thing (menstrual blood) in his mind and mouth and must eliminate it (Herdt 1982). Beginning at puberty for boys, and at first rather awkwardly performed, this spitting has become by the time the agent is an adult an experience, if not in fact a desire, that contains the pleasure of taking in and eliminating that which is so dangerous.

Underlying the ritual teachings is a sexual subjectivity that becomes explicit with development. For example, the growth of the penis, in the men's ritual 
pedagogy and practice, suggests the notion that the inseminations result in an elongation of the phallus as a 'pure product' of semen. The sense of this 'growth' is forever constitutive of a man's subjectivity of virility and masculinity as he approaches sexual relations with boys and then later contemplates the dangers of sex with women. This sense of timelessness pervades the formation of male subject/object desires and subjectivity in the lifelong practice of ritual secrecy. Adult men cannot do without the barrier of ritual secrecy that separates them and enables their agency in sometimes tense and challenging situations, requiring deceit and manipulation on a personal level. In short, the subjectivity of secret maleness calls to mind the ideology of Maurice Godelier's Great Man, instilled through a split image, the public adult warrior's mature phallic body on the one hand, and the secret subjective body that is still 'growing' as if he were a boy, on the other. This is how the Sambia embodied the objectification of the male body.

As I have often written, there is a sexual paradox in Sambia society. The men have the semen, they are the warriors, they hold the power, and they are the stakeholders in a patriarchal society where descent and property flow down the male line. And yet in Sambia sexual scripts, males are the objects of sexual attraction - that is, they lack agency and are objectified. How is it possible, in such a highly male-dominated, patriarchal culture, that men would be treated as the poster objects? Why would they want to be the desired sexual objects anyway?

As Godelier (1986) has remarked in discussing the neighbouring Baruya, the idealised and preferred sexual object and the object of beauty and attraction in many Melanesian cultures are not the female but the male. Not only is the male the most sexy and ornamented person, but also to desire him is normal and natural - for both genders. The Sambia Great Man is a warrior-hunter - strong, potent and powerfully erotic. He can take many wives and kill many men - a prominent theme in male folklore. It is a kind of glamour that is prestigious, intentional and performative; if you can do it, you are rewarded with sex and power. To bluff, to intimidate, to aggress and to attract are all linked.

The sexual objectification of Sambia males thus arises from two fundamental sources: 1) being more marginal, being subalterns, boys, not women, are the ones truly lacking a voice in their society until they are grown up - women are more powerful then men actually grant; and 2) men's power - that is, masculinityis conditional and highly permeable, beginning with the awkward and very cumbersome creation of a secret form of masculinity through insemination. It is this permeability of male power that ritual secrecy protects. What is hidden from public discourse is the secret ritual understanding that, to become potent 
and masculine, an adult man has to be inseminated by many men as he grows up. 'Desire' in this sexual culture is thus the product of, and is dependent upon, ritual secrecy and the cultural control of masculinity in the men's house.

Of course, it will easily be seen that public discussion of this idea would subject the men to scepticism and a variety of forms of accusation of exploitation and manipulation of women and younger boys. Men themselves acknowledge this when they say that they are 'bomwalyu' men - middle men - situated halfway between sex with the boys and sex with women, a reality they must hide from both sides. Ritual secrecy obviously protects this bisexuality from interrogation all around. But we should not doubt for one moment that the men are genuine, not cynical, in the belief that their inseminations make the boys into strong warriors, since they explain their own personal development in this same way. Cynicism is a luxury of the modern period that a people at war can ill afford.

What men are reproducing is their own (hegemonic) reality, a script that includes repackaging the desires and fears of the subaltern boys. The control of sexuality discourse was absolutely essential to this production. Secrecy was fragile; the material means of social regulation were limited; social arrangements were easily destabilised. Ritual secrecy within the institution of initiation was profound, but it required a violence and necessary brutality to create the desires and controls men needed. The terrible weakness in this system was that boys could not be trusted actually to accept or hold onto the secrecy, the rituals or the cultural reality that depended on it. And that worried the men, always.

The new initiate-before he has been socialised into the men's beliefs and practices - is not trusted and is to be feared because he might be an unwitting agent of destruction. He might unintentionally transmit pollution from his mother into the men's house. Likewise, he might unwittingly spill secrets and give away the military plans of his men's house should he enter into intimate relations with children or his mother. The anxiety of trust becomes part of all male development and all subsequent sexual subjectivity in adult men; no doubt this early trauma is reflected in the fear of men and fathers alike when they ponder the question: can we trust this boy?

Here again, the boy-initiate's compliance with the demands of the men's society to be inseminated by older adolescent bachelors serves as a general proxy for how the men assess their ability to trust a particular boy. One who agrees, who is objectified, who is thought to obey but also to intentionally follow the necessary taboos and ritual rules - such a boy is on his way to having authority in public affairs. The men gradually gain in their confidence of him, and his status rises. Perhaps he will become a Great Man, perhaps not. Thus, the rise in male agency is a direct expression of the boys' agreement with the men to be entrusted by them with their secret reality. 
Among the Sambia, the excitement of homo-sociality and boy-insemination drew upon both its fragile secrecy and the devotion to such privilege. Thus, the exclusion of women creates an idealised and fetishised Woman/Other, whose nature precludes understanding the ontology of being objectified in the homoerotic development of the male (Strathern 1988). Surely, we might think of this as a permanent misogyny, concomitant to conditional masculinity, which stems from too much liminality and too much gender segregation via permanent armed camps - harmful effects of a world at war. Sambia women are therefore sexual objects in a way very different than are the boys; they are denied sexual subjectivity and the status of equal social agents, for their role is but to reproduce a system that remains beyond their discursive control. Even more so, they could never understand its male purity and its male pleasures.

I have attempted in this chapter to reconsider our view of pleasure and sexual objectification, remembering the critical voices of Freud and Foucault, in the evolving understanding of sexuality, desire and social action in our society. If sexual repression and frustration, as Freud argued, include both fears and fantasies then the Sambia were right up there, with their institutionalised nosebleeding that imitated women's periods, homoerotic fellatio that symbolised breast feeding, and semen that was equated with mother's milk. These symbolic equations on the level of individual subjectivity enact a kind of sexual desire and expression unknown to our culture, while on the collective level these same ritual practices, in the logic of sexuality discourse, represent a deeper set of contradictions in the power system that cannot be named. In this cultural logic, boys were sexually objectified - meaning that a boy was developmentally obliged to hold in, to suppress feelings and probably wishes as well- that is, he was repressed. And it was ritual secrecy that institutionalised these controls, built up through ritual measures of power - a kind of domination control. The subaltern in this view was granted, by ritual, private experiences and secret relationships formative of a new self-not the selfhood of American middleclass society, with its constant talking about sex, but an incipient ritual agent increasingly empowered by an erotics of expression, and an expression of erotics, talked about in secret.

And these sexual dialectics were a package of ritual pleasures, both social and erotic, that Freud could never understand, as is clear from his remarks about the ancient Greeks. Pleasure can be a product of cultural things, of social arrangements meant to control sexuality, and even power relations that are not as hegemonic as Foucault imagined. After all these centuries, do any of us truly understand what happened in the formation of the cultural genius and the polymorphous, perverse erotics of Attic-culture Greece (Halperin 1990)?

I think it has always been difficult, in the history of culture and science, and lately in the social sciences in particular, to describe pleasure. We stand in awe 
of Freud that he took the project on in his Three Essays on the Theory of Sexuality (1904). His questions still intrigue us: are men bisexual? Can women fall in love with other women and still be heterosexual? Can children experiment sexually with masturbation or the same sex and still be normal? Today, however, we must insert our own Euro-American questions: can we allow discussion openly and frankly about what pleasure is without feeling the fear, shame and silence that surrounds the topic in so many communities? And why does the P-word (pleasure) remain so threatening, not just to male authority but to the middle class in general? These are questions of a postmodern society in transition, Internet savvy and no longer as sure a territory for discursive control as was nineteenth-century bourgeois France in Foucault's project.

A recent survey study of more than 11000 people in 29 countries by renowned sociologist Ed Laumann and colleagues (2003) from the University of Chicago has a surprising and counterintuitive finding, though it probably would not have surprised Freud: sexual satisfaction is inversely correlated with social power. The more patriarchal a country, the more controlling men are in a culture, the less sexual satisfaction men and women experience. And men in such controlling societies have much lower sexual satisfaction than their peers in more egalitarian societies. Shades of the Trobriand Islanders in the time of Malinowski! Power does not always breed pleasure, and powerful discursive controls over sexuality provide the least pleasure for men and women alike. I wonder what Foucault would have said to that?

In Secrecy and Cultural Reality, I suggested that anthropologists avoided taking seriously the power of ritual secrecy in its culture-building and developmental sexual effects, as per Freud, and its discursive effects in regulating social power, as per Foucault. I have posited that there was not only a colonising tendency to treat Melanesian ritual systems as 'child's play' - silly, unreal or symbolic, in the metaphor of the late Ian Hog bin (Herdt 2003). Concomitantly, there was another, more deeply avoidant tendency in the heterosexist and masculinist positionality of white male ethnographers to feel uncomfortable with these male Melanesian secrets. They were uncomfortable with male intimacy and homo-sociality in general and might have avoided anything that smacked of homoerotic events or settings (Herdt 2003:230-1). It sounds like an accusation, but it is meant to be more of an observation that situates each of us in our own time and place (Hammar 2010).

I believe that Don Tuzin's last book on the Ilahita men's society, The Cassowary's Revenge (1997), did respond to this implicit concern, when he suggested that Ilahita men were aware of their problematic position of both loving and fearing/ hating women. He went on to say that they needed a psychological outlet for their fears, which they found in the 'safe haven' of the men's cult house and its masculine sociality. Ilahita initiation allowed an objectification of males that 
substituted ritual scarification and fetishisation of female roles and tasks in secret settings, but without ritual homosexuality (Tuzin 1980). This last was seemingly a violation of masculine standards in Western society at the time and is notable in its own right.

By sexual and gender standards right up to the end of the 1980s, the period when Tuzin was writing, there was a terribly powerful and stigmatising attribution of disease, immaturity, sin, marginality and effeminacy to our cultural conceptions of homosexuality. Anthropology did not escape this medicalising tendency in the analogies, discursive metaphors and models that were selected for representation of same-sex relationships in the non-Western world (Herdt 1999). Freud was responsible for some of this pathologising, and Foucault was the reactor to it. All of us - male and female ethnographers alike - feared being identified with pariah states and categories; and male ethnographers could not quite see that our masculinity, as much as our friends, in New Guinea, was conditional and required the rejection of all things un-masculine: being dependent upon another man, being attracted to him, being in love with him (Herdt 2003). These discourses are experiences of anthropological unreality because there were no words, and no identity categories, to capture these personal meanings until very recently. It is too easy to retroactively make such interpretations from the perspective of the twenty-first century, though we can see how far the field has come in the kinds of ethnographies and the greater understanding of sexual diversity that they represent across cultures (Herdt 2006).

Let me close by returning to make a fundamental point about the relationship between the description of sexuality in our ethnographies and the understanding of how sexual discourse is regulated, even by the ethnographer. The self censors itself in modern society; in pre-colonial times among the Sambia, the self was symbolically censored by ritual secrecy. Contemporary sexuality remains censored and regulated, even in a society such as ours that is saturated with sex - that is, packaged sex - all the time. It seems impossible that it could be, but that part of Foucault's thesis was correct. The trouble we experience with this cultural barrier to free expression is different from what was imagined in Freud's time, when society and sociality were more stable, if less enlightened. And it is even different than in Foucault's time, since his tragic death from AIDS signified a new risk to sexual freedom unimagined before. Sexuality continues to test society, and probably always will, because it contains the possibility of the greatest liberation and the greatest oppression for the individual in the social contract that is culture. But I think that Freud and Foucault, while disagreeing on many things, were at least in agreement about that potential in sexuality for human development.

When societies such as the Sambia and kindred others in Melanesia placed so much social and psychological investment in secrecy, they were signalling 
their supreme discomfort with allowing individual choice in matters of desire, sex, love and marriage. The comparison with our own recent history-with its stigma and moralising and secrecy surrounding homosexuality, not to mention current controversy over same-sex marriage - is in the same league, though at a different level (Herdt 2009b). As our own society becomes more comfortable with these issues, we might expect the controversy to subside, with the resulting deregulation of sexuality, at least in certain domains. Secrecy, in this way, was never a friend of humanity, being the mother of invention in politically unstable societies, and ritual secrecy was a tremendously powerful albeit primitive way to thwart freedom in human development.

\section{Acknowledgments}

This chapter was originally delivered as the ASAO annual distinguished lecture in San Diego, California, in February 2006. I am grateful to the selection committee for the invitation and to the late Don Tuzin for his feedback on it.

\section{References}

Foucault, Michel 1980. The History of Sexuality. Volume 1: An Introduction. Robert Hurley (trans.). New York: Vintage Books.

Foucault, Michel 1995. Discipline and Punish: The Birth of the Prison. New York: Vintage.

Foucault, Michel 1997. Ethics: Subjectivity and Truth (Essential Works of Foucault, 1954-1984). New York: New Press.

Freud, Sigmund 1904. Three Essays on the Theory of Sexuality. New York: Basic Books.

Freud, Sigmund 1955 [1913]. Totem and Taboo. The Standard Edition. Volume 13. J. Strachey (ed. and trans.), pp. 1-164. London: Hogarth.

Godelier, Maurice 1982. Social Hierarchies Among the Baruya of New Guinea. In Andrew Strathern (ed.) Inequality in New Guinea Highlands Societies, pp. 3-34. New York: Cambridge University Press.

Godelier, Maurice 1986. The Making of Great Men: Male Domination and Power Among the New Guinea Baruya. Rupert Swyer (trans.). New York: Cambridge University Press. 
Halperin, David 1995. One Hundred Years of Homosexuality and Other Essays on Greek Love. New York: Routledge.

Hammar, Lawrence 2010. 'I Am An “MSM"!...I think': Melanesian Perspectives on Self, Risk, and Other in HIV Prevention. Paper presented to the Annual Meetings of the American Anthropological Association, New Orleans.

Herdt, Gilbert 1981. Guardians of the Flutes: Idioms of Masculinity. Chicago: University of Chicago Press.

Herdt, Gilbert 1982. Sambia Nose-bleeding Rites and Male Proximity to Women. Ethos 10:189-231.

Herdt, Gilbert 1984. Ritualized Homosexual Behavior in the Male Cults of Melanesia, 1862-1983: An Introduction. In Gilbert H. Herdt (ed.) Ritualized Homosexuality in Melanesia, pp. 1-82. Berkeley: University of California Press.

Herdt, Gilbert 1989. Father Presence and Masculine Development: The Case of Paternal Deprivation and Ritual Homosexuality Reconsidered. Ethos 18:32670 .

Herdt, Gilbert 1993. Introduction. In Gilbert H. Herdt (ed.) Ritualized Homosexuality in Melanesia, pp. vii-xliv. Berkeley: University of California Press.

Herdt, Gilbert 1999. Introduction: Sexual Cultures, Strange and Familiar. In Gilbert H. Herdt (ed.) Sambia Sexual Culture: Essays from the Field, pp. 1-28. Chicago: University of Chicago Press.

Herdt, Gilbert 2003. Secrecy and Cultural Reality. Ann Arbor, Mich.: University of Michigan Press.

Herdt, Gilbert 2006. The Sambia: Ritual, Sexuality, and Change in Papua New Guinea. New York: Thompson/Wadsworth.

Herdt, Gilbert 2009a. Introduction: Moral Panics, Sexual Rights, and Cultural Anger. In Gilbert Herdt (ed.) Moral Panics, Sex Panics: Fear and the Fight Over Sexual Rights, pp. 1-46. New York: New York University Press.

Herdt, Gilbert 2009b. Gay Marriage: The Panic and the Right. In Gilbert Herdt (ed.) Moral Panics, Sex Panics: Fear and the Fight Over Sexual Rights, pp. 157-204. New York: New York University Press.

Herdt, Gilbert and Robert J. Stoller 1990. Intimate Communications: Erotics and the Study of Culture. New York: Columbia University Press. 
Laumann E. O., A. Nicolosi, D. B. Glasser, A. Paik, C. Gingell, E. Moreira and T. Wang 2003. Sexual Problems Among Women and Men Aged 40-80 y.: Prevalence and Correlates Identified in the Global Study of Sexual Attitudes and Behaviors. International Journal of Impotence Research 17:39-57.

Mead, Margaret 1928. Coming of Age in Samoa: A Psychological Study of Primitive Youth for Western Civilization. New York: Morrow.

Stolpe, Birgitta 2003. Cultural Endocrinology: Menarche, Modernity, and the Transformative Power of Social Reconfigurations. PhD Dissertation, Committee on Human Development, Department of Psychology, University of Chicago.

Strathern, Marilyn 1988. The Gender of the Gift. Berkeley: University of California Press.

Tuzin, Donald F. 1980. The Voice of the Tambaran: Truth and Illusion in Ilahita Arapesh Religion. Berkeley: University of California Press.

Tuzin, Donald F. 1997. The Cassowary's Revenge: The Life and Death of Masculinity in a New Guinea Society. Chicago: University of Chicago Press.

Young, Michael 2004. Malinowski: Odyssey of An Anthropologist. New Haven, Conn.: Yale University Press. 